\title{
'Ray Ruby' Grapefruit Affected by Huanglongbing I. Planting Density and Soil Nutrient Management
}

\author{
Dinesh Phuyal \\ University of Florida, Institute of Food and Agricultural Sciences, Indian \\ River Research and Education Center, 2199 South Rock Road, Fort Pierce, \\ FL 34945
}

\section{Thiago Assis Rodrigues Nogueira}

São Paulo State University, School of Engineering, Department of Plant Protection, Rural Engineering and Soils, 56 Brasil Sul Avenue, Ilha Solteira, SP 15385-000, Brazil

Arun D. Jani

University of Florida, Institute of Food and Agricultural Sciences, Indian River Research and Education Center, 2199 South Rock Road, Fort Pierce, FL 34945

\author{
Davie M. Kadyampakeni \\ University of Florida, Institute of Food and Agricultural Sciences, Citrus Research \\ and Education Center, 700 Experiment Station Road, Lake Alfred, FL 33850
}

Kelly T. Morgan

University of Florida, Institute of Food and Agricultural Sciences, Southwest Florida Research and Education Center, 2685 State Road 29 North, Immokalee, FL 34142

\section{Rhuanito Soranz Ferrarezi}

University of Florida, Institute of Food and Agricultural Sciences, Indian River Research and Education Center, 2199 South Rock Road, Fort Pierce, FL 34945

Additional index words. controlled-release fertilizer, fruit quality, fruit yield, planting spacing, tree health

\begin{abstract}
Huanglongbing (HLB), or citrus greening disease, affects practically all fruitbearing trees in commercial citrus orchards in Florida with no cure identified yet. Highdensity plantings and enhanced nutritional programs such as application of controlledrelease fertilizer (CRF) with higher micronutrient levels can mitigate disease symptoms and extend the tree life span of sweet oranges (Citrus sinensis). The objective of this study was to evaluate the effects of tree planting density and application of CRF blends differing in $\mathbf{N}$ to $\mathrm{K}$ ratio and micronutrient content on grapefruit (Citrus paradisi) plant health, canopy volume, fruit yield, and fruit quality in an HLB-affected orchard. A study was conducted in Florida for two growing seasons (2017-18 and 2018-19) to evaluate the response of 'Ray Ruby' grapefruit on Kuharske citrange (Citrus sinensis $\times$ Poncirus trifoliata) to three planting densities $(300,440$, and 975 trees per ha) and two CRF blends [12 nitrogen $(N)-1.31$ phosphorus $(P)-7.47$ potassium $(K)$ and $16 \mathrm{~N}-1.31 \mathrm{P}-16.6 \mathrm{~K}$ ] with different nutrient sources and composition. According to quantitative real-time polymerase chain reaction testing, all sampled trees tested positive for Candidatus Liberibacter asiaticus, the pathogen associated with HLB. Trees planted at 975 trees per ha had $33 \%$ lower canopy volume per tree but $160 \%$ greater fruit yield per hectare and $190 \%$ higher yield of solids compared with 300 trees per ha. Fruit produced in high-density planting (975 trees per ha) was $18 \%$ more acidic with higher soluble solid compared with low-density planting (300 trees per ha). The use of a CRF blend with higher amounts of micronutrients along with lower $K$ increased canopy volume in both seasons and resulted in $24 \%$ and $29 \%$ reduction in fruit yield per hectare and yield of solids, respectively, in 2017-18. Our results indicate that high-density plantings increase fruit yield per area, and regardless of the $N$ to $K$ ratio, the use of CRF blends supplemented with micronutrients may not increase fruit yield in HLB-affected grapefruit.
\end{abstract}

HLB or citrus greening poses a serious threat to the Florida citrus industry since almost all mature trees in commercial orchards are affected by the disease ( $\mathrm{Li}$ et al.,
2019). HLB decreases fruit yield and quality, and trees become unproductive and prone to perish depending on disease severity (Farnsworth et al., 2014; Moreira et al., 2019). Total citrus production has decreased rapidly from 7.8 to 2.2 million tons since the disease discovery in Florida in 2005 [U.S. Department of Agriculture (USDA), 2018]. The pathogen associated to HLB in Florida is the phloemlimiting bacteria Candidatus Liberibacter asiaticus (CLas), which is transmitted by the Asian citrus psyllid (Diaphorina citri).

There is currently no known cure for HLB, and horticultural management practices can be used to alleviate disease severity and maintain orchard profitability (Halbert and Manjunath, 2004). Some approaches include elimination of inoculum (Xia et al., 2011), enhanced nutritional programs alone or in conjunction with pesticides (Morgan et al., 2016; Stansly et al., 2014; Vashisth and Grosser, 2018), adoption of tolerant scions and rootstocks (Castle et al., 2019), application of hormones, antibiotics, and thermotherapy (Li et al., 2019), and production of citrus under protective screening (Ferrarezi et al., 2019). Additional research is needed to better understand the impact of tree planting density and the use of higher micronutrient application through fertilizers on citrus productivity under HLB-endemic conditions in Florida.

Because HLB-affected trees have higher production costs and lower fruit yield (Farnsworth et al., 2014), it is crucial to determine the relationship between tree density, fruit yield, and fruit quality. At present, tree density has become a critical consideration in new citrus plantings as more trees per area increase yields and provide early returns of investment as HLB tends to reduce yield over time. Previous studies have shown that high-density plantings can result in higher fruit yields, albeit with a higher initial investment (Dalal et al., 2013; Singerman et al., 2018). In HLB-endemic regions, highdensity plantings resulted in lower cumulative HLB incidence, likely due to the lower psyllid to plant ratio (Moreira et al., 2019). Additionally, removing HLB symptomatic trees in high-density planting areas may reduce the proportion of HLB-affected trees resulting in greater profitability for growers.

HLB-affected trees have a compromised root system with reduced nutrient and water uptake from the soil (Johnson et al., 2014). Because trees do not use all the nutrients applied, there is potential for fertilizer leaching and water resources contamination (Obreza and Sartain, 2010). An alternative to conventional dry granular fertilizers is the use of CRF to slow down the nutrient release process. With CRF, prills are surrounded by a semipermeable membrane activated by soil moisture and temperature. When the outer membrane is wetted, it slowly releases nutrients by creating micropores through the coating film, resulting in constant nutrient supply and higher nutrient use efficiency (Irfan et al., 2018; Morgan et al., 2009; Obreza et al., 2006). Nutrients are slowly released into the soil, reducing potential losses by leaching or volatilization and creating a nutrient reservoir (Spyke et al., 2017). Use of CRF can result in greater fruit yields and quality 
(Kadyampakeni et al., 2015; Obreza et al., 2006; Zekri and Koo, 1992), constantly nutrient supply to citrus trees affected by HLB (Vashisth and Grosser, 2018), and higher N fertilization efficiency (Morgan and Kadyampakeni 2020; Obreza et al., 1999, 2006).

Trees compromised by HLB tend to show micronutrient deficiencies, particularly manganese $(\mathrm{Mn})$ and zinc $(\mathrm{Zn})$. Foliar sprays are widely used to apply micronutrients but are more expensive than soil-applied granular fertilizers (Kadyampakeni et al., 2015; Tansey et al., 2017). Furthermore, foliar micronutrient application is challenging in Florida due to high temperatures, frequent wind, and regular rainfall events, all of which promote CRF as the best way to synchronize nutrient release with plant demand. Elevating soil micronutrient concentrations in HLB-affected trees may increase root biomass and canopy growth (Spyke et al., 2017). Soil micronutrient application of CRFs to improve grapefruit productivity has not been thoroughly investigated yet. Zambon et al. (2019) found that soil application of Mn can improve vascular function of HLB-affected sweet orange trees. There is a need to evaluate the efficacy of soil nutrient management on the performance of grapefruit on poorly drained Florida coastal Flatwood soils. We hypothesized that 1) high-density plantings result in higher fruit yield per area without compromising fruit quality and 2) HLB-affected trees require continuous application of nutrients, particularly micronutrients, to mitigate plant disease, ameliorate canopy volume, increase trunk diameter, increase fruit yield, and improve fruit quality. The objective of this study was to evaluate how tree density and soil nutrient application affects grapefruit tree growth and fruit yield parameters under HLB-endemic conditions.

\section{Materials and Methods}

Study site. The study was conducted at the University of Florida Institute of Food and Agricultural Sciences (UF/IFAS) Indian River Research and Education Center in Fort Pierce, FL (lat. $27^{\circ} 26^{\prime} 08.2^{\prime \prime} \mathrm{N}$, long.

Received for publication 23 Apr. 2020. Accepted for publication 18 June 2020 .

Published online 31 July 2020.

Funding for this research was provided by UF/ IFAS Citrus Initiative.

We thank Dr. Mark Ritenour, Dr. Jude Grosser, Tom James, Randy Burton, Hernan Soto, Cristina Gil, Andres Gonzalez, Clarence King, Donald Davis, Taylor Meadows, Megan Eckman, Benjamin Holly, and Peter Spyke for the technical assistance; Harrell's Fertilizers (Trey Whitehurst, Erik Kellim, and Matt Shook) for fertilizer donation; and Dr. Ozgur Batuman at the UF/IFAS Southwest Florida Research and Education Center in Immokalee, FL for the Candidatus Liberibacter Asiaticus Diagnostic.

R.S.F. is the corresponding author. E-mail: rferrarezi@ ufl.edu.

This is an open access article distributed under the CC BY-NC-ND license (https://creativecommons. org/licenses/by-nc-nd/4.0/). $80^{\circ} 26^{\prime} 43.2^{\prime \prime} \mathrm{W}$, and altitude of $8 \mathrm{~m}$ ). Weather data were monitored by the Florida Automated Weather Network system by a station located $20 \mathrm{~km}$ away from the experimental site (St. Lucie station) (Fig. 1).

Plant material. Four-year-old 'Ray Ruby' grapefruit trees on Kuharske citrange (Citrus sinensis $\times$ Poncirus trifoliata) rootstock planted in Sept. 2013 was used as plant material. The study was conducted for two seasons (2017-18 and 2018-19).

Experimental design and treatments. The experiment was conducted in a split-plot design with four replications (Table 1). We tested three planting densities \{ single row low-density $(\mathrm{SR} / \mathrm{LD})(4.5 \times 7 \mathrm{~m}, 300$ trees per ha), single row high-density (SR/HD) $(3 \times 7 \mathrm{~m}, 440$ trees per ha), and double-row high-density staggered in diamond setting $(\mathrm{DR} / \mathrm{HD})[(2.7 \times 1.5 \times 1 \mathrm{~m}) \times 6 \mathrm{~m}, 975$ trees per ha] $\}$ and two CRF blends (Harrell's, Lakeland, FL). The first blend tested was
$16-3-20(16 \mathrm{~N}-1.31 \mathrm{P}-16.6 \mathrm{~K})$ with $81 \%$ of $\mathrm{N}$ and $50 \%$ of $\mathrm{K}$ as $\mathrm{CRF}$, with iron $(\mathrm{Fe})$ as chelates and all other micronutrients as sulfates, which was blended based on soil analysis and plant nutrient requirements following the recommendations of Morgan and Kadyampakeni (2020). The second blend was $12-3-9 \quad(12 \mathrm{~N}-1.31 \mathrm{P}-7.47 \mathrm{~K})$ with $100 \%$ of $\mathrm{N}$ and $\mathrm{P}$ and $95 \%$ of $\mathrm{K}$ as CRF, with iron as chelates and all other micronutrients as sulfur-coated products. Micronutrients were blended based on the need to increase micronutrient content applied as CRF. Sulfur (S) was added to reduce soil $\mathrm{pH}$. The blends tested $(12 \mathrm{~N}-$ $1.31 \mathrm{P}-7.47 \mathrm{~K}$ and $16 \mathrm{~N}-1.31 \mathrm{P}-16.6 \mathrm{~K})$ had $\mathrm{N}$ to $\mathrm{K}$ ratios of $1: 0.75$ and $1: 1.25$, respectively (Table 2). The CRF amount applied was calculated based on $\mathrm{N}$ recommendations for grapefruit in Florida (180 kg.ha ${ }^{-1}$ of N) as outlined by Morgan and Kadyampakeni (2020). Both blends had a 4-month release
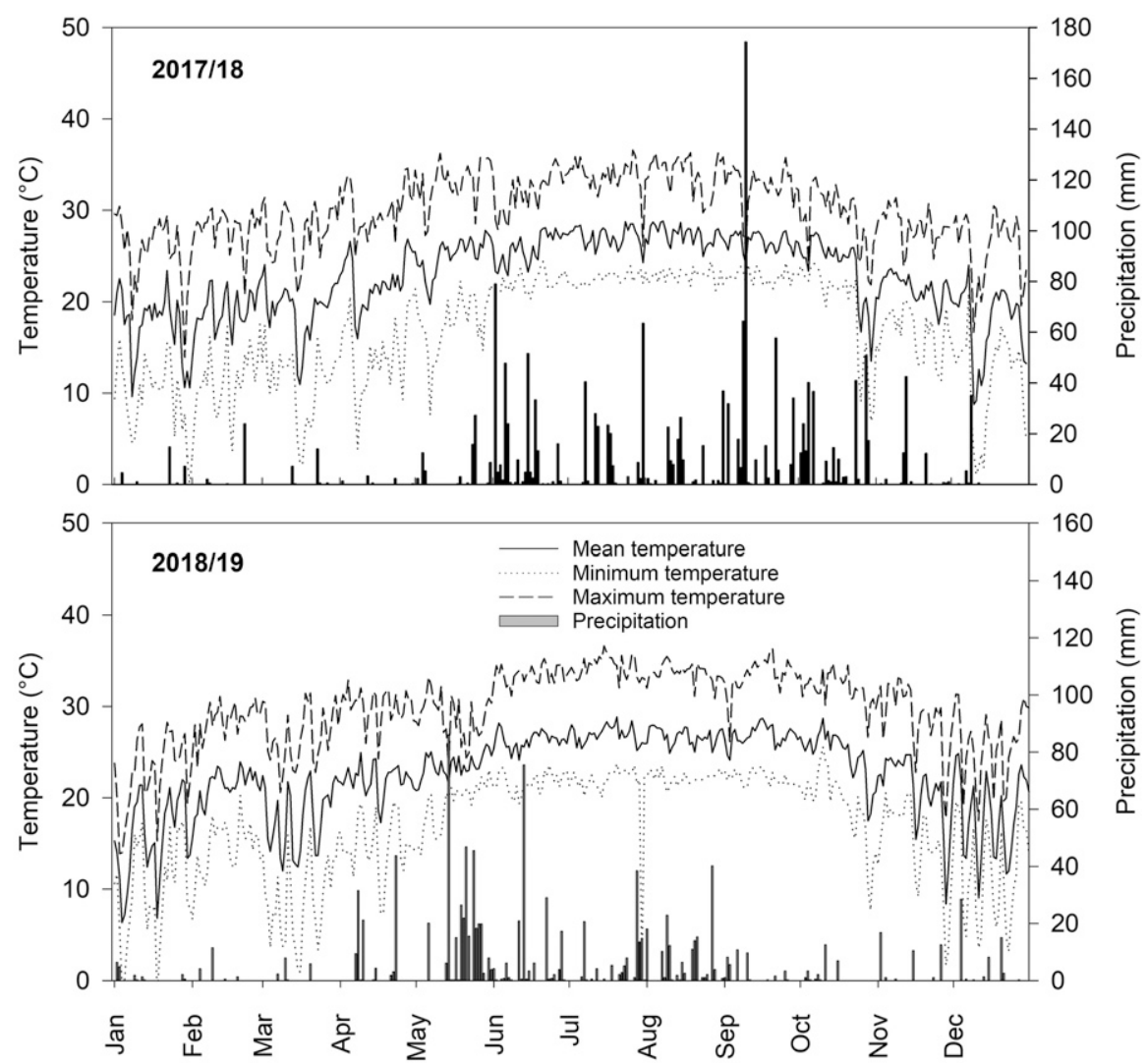

Fig. 1. Temperature and precipitation data collected by Florida Automated Weather Network using the St. Lucie West weather station in 2017-18 and 2018-19.

Table 1. Brief description of the experimental design.

\begin{tabular}{ll}
\hline Treatment design & Factor and level \\
\hline Main plot & Controlled-release fertilizer (CRF) application in the soil \\
& 1. (16-3-20) $16 \mathrm{~N}-1.31 \mathrm{P}-16.6 \mathrm{~K}$ with $81 \%$ of $\mathrm{N}$ and $50 \%$ of $\mathrm{K}$ as \\
CRF with iron as chelates and all other micronutrients as sulfates & 2. (12-3-9) $12 \mathrm{~N}-1.31 \mathrm{P}-7.47 \mathrm{~K}$ with $100 \%$ of $\mathrm{N}$ and $\mathrm{P}$, and $95 \%$ of $\mathrm{K}$ as \\
& CRF with iron as chelates and all other micronutrients as \\
sulfur-coated products at higher rate \\
Planting density \\
1. Single row low-density (SR/LD): 300 trees per ha \\
2. Single row high-density (SR/HD): 440 trees per ha \\
3. Double-row high-density (DR/HD): 975 trees per ha \\
\hline
\end{tabular}


Table 2. The nutrient composition and amount applied in two controlled-release fertilizer (CRF) blends.

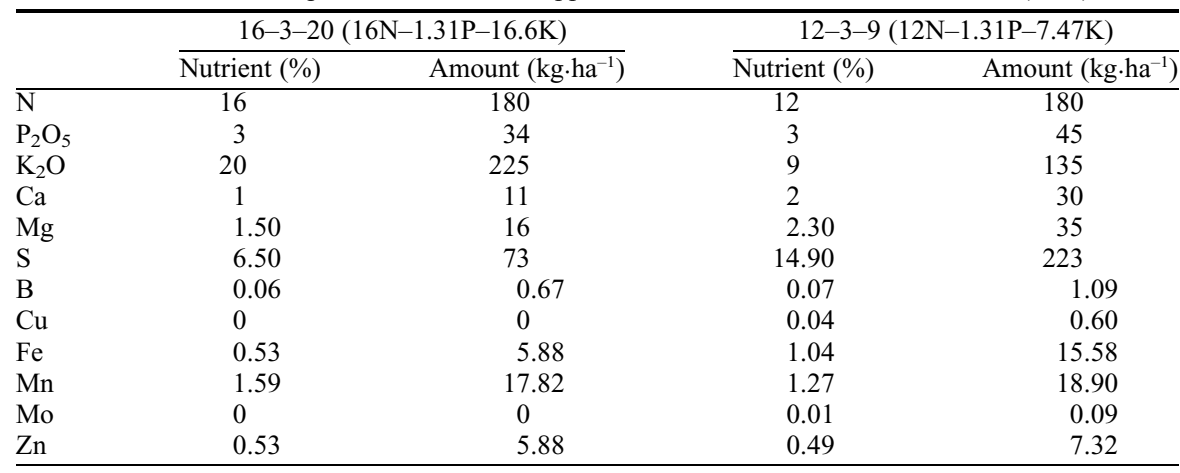

Table 3. Cycle threshold (Ct) value of Candidatus Liberibacter asiaticus (CLas) DNA as a function of controlled-release fertilizer (CRF) and tree planting density (PD) in 2017-18 and 2018-19.

\begin{tabular}{|c|c|c|}
\hline \multirow[b]{2}{*}{ Treatment } & \multicolumn{2}{|c|}{$\mathrm{Ct}$ value of $C$ Las DNA } \\
\hline & $2017-18$ & $2018-19$ \\
\hline \multicolumn{3}{|l|}{$\overline{\mathrm{CRF}^{\mathrm{z}}}$} \\
\hline $12-3-9$ & $25.98 \pm 1.60^{y}$ & $24.70 \pm 0.38$ \\
\hline $16-3-20$ & $25.45 \pm 1.05$ & $25.45 \pm 0.41$ \\
\hline \multicolumn{3}{|l|}{$\mathrm{PD}^{\mathrm{x}}$} \\
\hline $\mathrm{SR} / \mathrm{LD}$ & $27.69 \pm 2.23$ & $25.10 \pm 0.49$ \\
\hline $\mathrm{SR} / \mathrm{HD}$ & $23.88 \pm 0.55$ & $25.34 \pm 0.61$ \\
\hline $\mathrm{DR} / \mathrm{HD}$ & $25.58 \pm 1.55$ & $24.79 \pm 0.42$ \\
\hline Sources of variation & & \\
\hline CRF & $0.7930^{\mathrm{NS}}$ & $0.1148^{\mathrm{NS}}$ \\
\hline PD & $0.2534^{\mathrm{NS}}$ & $0.5445^{\mathrm{NS}}$ \\
\hline $\mathrm{CRF}^{*} \mathrm{PD}$ & $0.2146^{\mathrm{NS}}$ & $0.0013 * *$ \\
\hline
\end{tabular}

${ }^{\mathrm{z}} 12 \mathrm{~N}-1.31 \mathrm{P}-7.47 \mathrm{~K}$ and $16 \mathrm{~N}-1.31 \mathrm{P}-16.6 \mathrm{~K}$.

${ }^{\mathrm{y}}$ Means $\pm \mathrm{SE}(\mathrm{n}=4)$ followed by different lowercase letters are significantly different at the $P<0.05$ level by Tukey's test.

${ }^{\mathrm{x}} \mathrm{SR} / \mathrm{LD}=$ single row low-density (300 trees per ha). $\mathrm{SR} / \mathrm{HD}=$ single row high-density (440 trees per ha). $\mathrm{DR} / \mathrm{HD}=$ double-row high-density staggered in diamond setting ( 975 trees per ha).

Ns, $*, * *, * * *$ Nonsignificant or significant at $P<0.05,0.01$, or 0.001 , respectively.

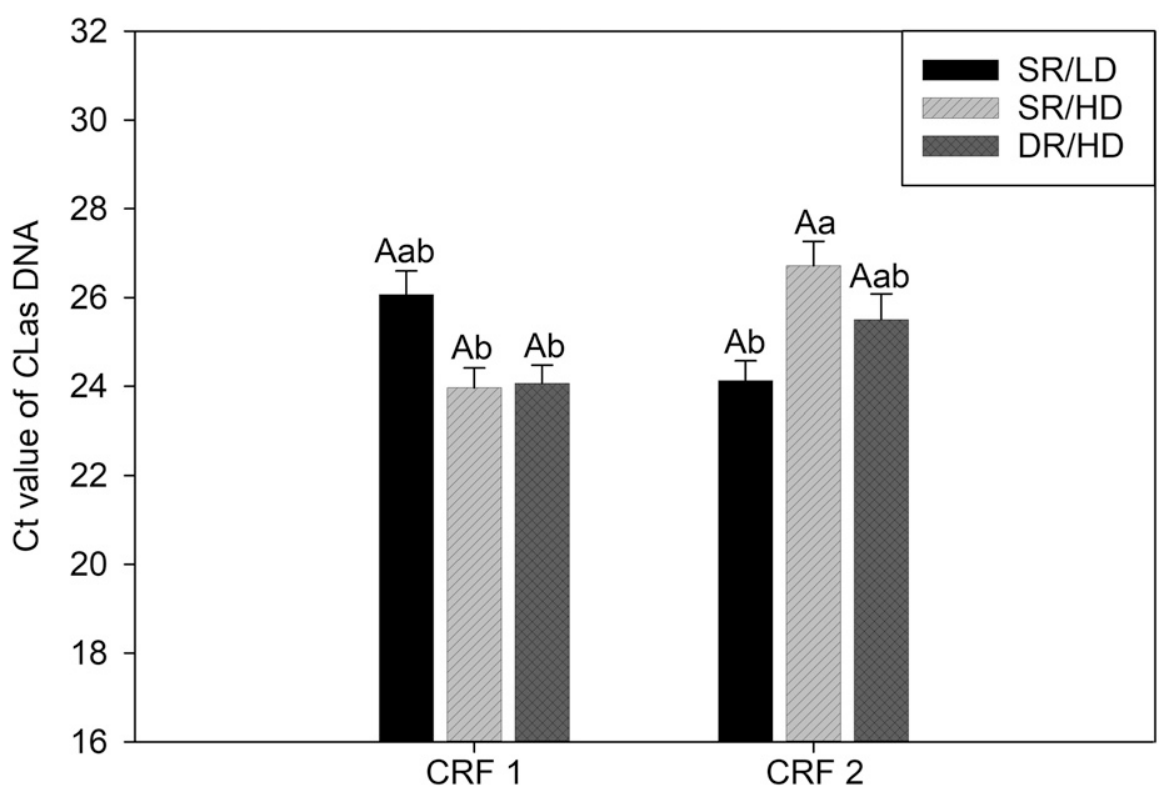

Fig. 2. Cycle threshold (Ct) value of Candidatus Liberibacter asiaticus (CLas) DNA in plant leaf tissue under two controlled-release fertilizer (CRF) blends: CRF $1(12 \mathrm{~N}-1.31 \mathrm{P}-7.47 \mathrm{~K})$ and CRF $2(16 \mathrm{~N}-$ $1.31 \mathrm{P}-16.6 \mathrm{~K})$; and three planting density [single row low-density (SR/LD), single row high-density (SR/HD), and double-row high-density staggered in diamond setting (DR/HD)]. Means \pm sE followed by different letters (uppercase compare CRF and lowercase compare PD) are significantly different by Tukey's test at $P<0.05$. period and were applied in equal amounts in February, July, and October. The amount applied per tree was calculated by assuming a total of 358 trees per ha, which approximates the Florida average (Singerman et al., 2018). Each tree received the same amount of nutrients regardless of planting density. Fertilizer was applied manually under the dripline avoiding row middles in the single-row spacing as recommended by Morgan and Kadyampakeni (2020). For DR/HD, fertilizer was applied in the tree canopy area around each individual tree.

The experimental area consisted of 2.13 ha arranged as eight raised beds (15.25 m wide $\times 175 \mathrm{~m}$ long) with two tree rows per bed. Beds were divided into three experimental units $(58.33 \mathrm{~m}$ long) for a total of 24 experimental units. Each tree density planting plot had a total of 26 , 38 , and 84 trees in the SR/LD, SR/HD, and DR/HD treatments, respectively, totaling 1184 trees in the entire experimental area. Each plot consisted of two tree rows with one tree on each end kept as border tree.

Soil type and orchard layout. Trees were planted on a Pineda soil series, classified as loamy, siliceous, active hyperthermic Arenic Glossaqualfs (USDA, 2020). The land represents a natural slope of $0 \%$ to $2 \%$. The soil was poorly drained and had $96 \%$ sand, $2.5 \%$ silt, and $1.5 \%$ clay with $0.5 \%$ to $2.0 \%$ organic matter. The $\mathrm{pH}$ value and the cation-exchange capacity (CEC) in these soils generally range from 5.6 to 7.3 and 2 to $6 \mathrm{cmol}_{\mathrm{c}} \cdot \mathrm{kg}^{-1}$, respectively (Morgan and Kadyampakeni, 2020).

Trees were watered using a microsprinkler irrigation system with one microsprinkler per tree (40 blue nozzle size $40.5 \mathrm{~L}$ per h; Bowsmith, Exeter, CA) in treatments with 300 and 440 trees per ha, and one microsprinkler per two trees at 975 trees per ha. The irrigation controller (HI10000Pro; Hanna Instruments, Woonsocket, RI) was programmed to irrigate trees twice per day. The amount of water applied was adjusted based on the equation derived using the canopy area, the class A pan evaporation in inches per day, and the pan evaporation factor (Wright, 2000).

The treatment planted at 300 trees per ha (SR/LD) was spaced at $4.5 \times 7 \mathrm{~m}$, and the one with 440 trees per ha $(\mathrm{SR} / \mathrm{HD})$ at $3 \times 7 \mathrm{~m}$ (inrow $\times$ between-row). The treatment planted at 975 trees per ha $(\mathrm{DR} / \mathrm{HD})$ was spaced in diamond setting $[(2.7 \times 1.5 \times 1 \mathrm{~m}) \times 6 \mathrm{~m}]$, with double rows spaced at $1 \mathrm{~m}$. Trees were arranged in a triangular shape so herbicides could be sprayed without obstruction from adjacent trees on either side. The orchard maintenance and caretaking followed standard UF/IFAS best management practices (Vincent et al., 2019).

Concentration of CLas DNA in plant leaf tissue. Leaf samples were collected in April to determine the concentration of CLas DNA in plant leaf tissue. Symptomatic, fully expanded, and hardened mature leaves were collected with the leaf petiole attached. 
Samples were taken from branches with mottled leaves from all areas in the canopy. Eight random trees were chosen per plot, excluding border trees, to collect leaf samples. Samples were placed in a sealable plastic bags and in a cooler with ice to prevent heat damage. Samples were analyzed by quantitative real-time polymerase chain reaction (PCR) (Li et al., 2006). The cycle threshold $(\mathrm{Ct})$ value is the minimum number of DNA amplification cycles necessary to detect a fluorescent signal. Several studies confirmed DNA extracted from the leaf with a $\mathrm{Ct}$ value less than 32 is considered $C$ Las-
Table 4. Trunk diameter and canopy volume as a function of controlled-release fertilizer (CRF) and planting density (PD) in 2017-18 and 2018-19.

\begin{tabular}{|c|c|c|c|c|}
\hline \multirow[b]{2}{*}{ Treatment } & \multicolumn{2}{|c|}{ Trunk diam (mm) } & \multicolumn{2}{|c|}{ Canopy volume $\left(\mathrm{m}^{3}\right)$} \\
\hline & $2017-18$ & $2018-19$ & $2017-18$ & $2018-19$ \\
\hline \multicolumn{5}{|l|}{$\overline{\mathrm{CRF}^{\mathrm{z}}}$} \\
\hline $12-3-9$ & $75.61 \pm 0.82^{y}$ & $82.50 \pm 0.49$ & $6.74 \pm 0.18 \mathrm{a}$ & $8.25 \pm 0.13 \mathrm{a}$ \\
\hline $16-3-20$ & $75.45 \pm 0.71$ & $81.50 \pm 0.48$ & $6.09 \pm 0.15 b$ & $7.52 \pm 0.12 b$ \\
\hline \multicolumn{5}{|l|}{$\mathrm{PD}^{\mathrm{x}}$} \\
\hline $\mathrm{SR} / \mathrm{LD}$ & $81.45 \pm 0.77 \mathrm{a}$ & $88.85 \pm 0.51 \mathrm{a}$ & $7.16 \pm 0.19 \mathrm{a}$ & $9.19 \pm 0.16 \mathrm{a}$ \\
\hline $\mathrm{SR} / \mathrm{HD}$ & $78.50 \pm 0.65 \mathrm{a}$ & $84.87 \pm 0.46 b$ & $7.03 \pm 0.20 \mathrm{a}$ & $8.55 \pm 0.14 b$ \\
\hline $\mathrm{DR} / \mathrm{HD}$ & $66.63 \pm 0.80 \mathrm{~b}$ & $73.33 \pm 0.50 \mathrm{c}$ & $5.05 \pm 0.17 \mathrm{~b}$ & $6.13 \pm 0.12 \mathrm{c}$ \\
\hline Sources of variation & \multicolumn{4}{|c|}{$P$ value } \\
\hline $\mathrm{CRF}$ & $0.8535^{\mathrm{NS}}$ & $0.0815^{\mathrm{NS}}$ & $0.0026 * *$ & $<0.0001^{* * *}$ \\
\hline PD & $<0.0001 * * *$ & $<0.0001 * * *$ & $<0.0001 * * *$ & $<0.0001 * * *$ \\
\hline $\mathrm{CRF} * \mathrm{PD}$ & $0.0982^{\mathrm{NS}}$ & $0.5726^{\mathrm{NS}}$ & $0.1261^{\mathrm{NS}}$ & $0.4100^{\mathrm{NS}}$ \\
\hline
\end{tabular}

${ }^{\mathrm{z}} 12 \mathrm{~N}-1.31 \mathrm{P}-7.47 \mathrm{~K}$ and $16 \mathrm{~N}-1.31 \mathrm{P}-16.6 \mathrm{~K}$.

${ }^{\mathrm{y}}$ Means $\pm \mathrm{SE}(\mathrm{n}=32)$ followed by different lowercase letters are significantly different at the $P<0.05$ level by Tukey's test.

${ }^{\mathrm{x}} \mathrm{SR} / \mathrm{LD}=$ single row low-density ( 300 trees per ha). $\mathrm{SR} / \mathrm{HD}=$ single row high-density (440 trees per ha). $\mathrm{DR} / \mathrm{HD}=$ double-row high-density staggered in diamond setting ( 975 trees per ha).

Ns, $* * *, * *$ Nonsignificant or significant at $P<0.05,0.01$, or 0.001 , respectively. positive (Albrecht and Bowman, 2011; Gottwald et al., 2012; Shin and van Bruggen, 2018; Stansly et al., 2014).

Tree growth. Tree growth was measured each year in December before fruit harvest. Eight trees were selected randomly in each plot excluding border trees. Trunk diameter was measured at $8 \mathrm{~cm}$ above the graft union in a north-south direction using a digital caliper. Tree height was measured from the soil surface perpendicular to the tallest leaf or branch using a meter stick (Model No. 98024; Seco Manufacturing, Mound City, IL). Canopy width or diameter was measured parallel (north-south direction) and perpendicular (east-west direction) to the tree row. Canopy volume was calculated by using the geometric prolate spheroid equation described by Obreza and Rouse (1993): [(4/3) $(\pi)$ (tree height/2) (average canopy diameter $)^{2}$.

Fruit number, size, and yield. For determination of fruit number and size, fruit from eight trees per plot, excluding border trees, were sorted by an optical sizer (Autoline; Reedley, CA). Tiny, diseased, and damaged fruit were discarded. The sorter was programmed to categorize fruit size into the

Table 5. Total number of fruit, fruit diameter, fruit yield per tree, and fruit yield per area as a function of controlled-release fertilizer (CRF) and tree planting density (PD) in 2017-18 and 2018-19.

\begin{tabular}{|c|c|c|c|c|c|c|c|c|}
\hline \multirow[b]{2}{*}{ Treatment } & \multicolumn{2}{|c|}{ Total no. of fruit } & \multicolumn{2}{|c|}{ Fruit diam $(\mathrm{mm})$} & \multicolumn{2}{|c|}{ Fruit yield per tree $(\mathrm{kg})$} & \multicolumn{2}{|c|}{ Fruit yield per area $\left(\mathrm{kg} \cdot \mathrm{ha}^{-1}\right)$} \\
\hline & $2017-18$ & 2018-19 & $2017-18$ & $2018-19$ & $2017-18$ & $2018-19$ & $2017-18$ & 2018-19 \\
\hline $12-3-9$ & $25.42 \pm 1.63 \mathrm{~b}^{y}$ & $27.71 \pm 2.54$ & $100.90 \pm 1.15$ & $96.53 \pm 0.65$ & $10.67 \pm 0.60 \mathrm{~b}$ & $9.56 \pm 0.90$ & $5,588.03 \pm 368.27 b$ & $4,973.00 \pm 515.38$ \\
\hline $\mathrm{SR} / \mathrm{LD}$ & $34.02 \pm 2.29 \mathrm{a}$ & $27.78 \pm 3.10$ & $102.75 \pm 2.29$ & $97.27 \pm 3.10$ & $12.90 \pm 0.78 \mathrm{ab}$ & $9.04 \pm 1.04$ & $3,782.95 \pm 231.59 c$ & $2,651.67 \pm 304.75 b$ \\
\hline $\mathrm{SR} / \mathrm{HD}$ & $29.61 \pm 2.42 \mathrm{ab}$ & $27.81 \pm 2.95$ & $102.28 \pm 2.42$ & $97.12 \pm 0.79$ & $13.19 \pm 1 \mathrm{a}$ & $9.47 \pm 1.10$ & $5,654.64 \pm 429.58 \mathrm{~b}$ & $4,061.69 \pm 469.91 \mathrm{ab}$ \\
\hline $\mathrm{DR} / \mathrm{HD}$ & $26 \pm 1.74 b$ & $20.44 \pm 2.37$ & $100.66 \pm 1.74$ & $94.46 \pm 3.19$ & $10.27 \pm 0.65 b$ & $7.10 \pm 0.79$ & $9,967.98 \pm 633.74 \mathrm{a}$ & $6,886.30 \pm 770.91 \mathrm{a}$ \\
\hline $\mathrm{CRF}$ & 0.0004 & $0.1484^{\mathrm{NS}}$ & $0.1082^{\mathrm{NS}}$ & $0.8235^{\mathrm{NS}}$ & $0.0026 * * *$ & $0.0759^{\mathrm{NS}}$ & $0.0006^{* * *}$ & $0.1718^{\mathrm{NS}}$ \\
\hline $\mathrm{PD}$ & $0.0322^{\mathrm{NS}}$ & $0.1074^{\mathrm{NS}}$ & $0.3494^{\mathrm{NS}}$ & $0.5159^{\mathrm{NS}}$ & $0.0214 *$ & $0.1965^{\mathrm{NS}}$ & $<0.0001 * * *$ & $<0.0001 * * *$ \\
\hline CRF*PD & $0.6181^{\mathrm{NS}}$ & $0.4392^{\mathrm{NS}}$ & $0.3064^{\mathrm{NS}}$ & $0.2620^{\mathrm{NS}}$ & $0.5317^{\mathrm{NS}}$ & $0.6685^{\mathrm{NS}}$ & $0.0570^{\mathrm{NS}}$ & $0.8929^{\mathrm{NS}}$ \\
\hline
\end{tabular}

${ }^{\mathrm{z}} 12 \mathrm{~N}-1.31 \mathrm{P}-7.47 \mathrm{~K}$ and $16 \mathrm{~N}-1.31 \mathrm{P}-16.6 \mathrm{~K}$.

${ }^{\mathrm{y}}$ Means \pm SE $(\mathrm{n}=32)$ followed by different lowercase letters are significantly different at the $P<0.05$ level by Tukey's test.

${ }^{\mathrm{x}} \mathrm{SR} / \mathrm{LD}=$ single row low-density (300 trees per ha). $\mathrm{SR} / \mathrm{HD}=$ single row high-density $(440$ trees per ha). $\mathrm{DR} / \mathrm{HD}=$ double-row high-density staggered in diamond setting ( 975 trees per ha).

NS, *,**,**Nonsignificant or significant at $P<0.05,0.01$, or 0.001 , respectively.

Table 6. Soluble solids content, titratable acidity, ratio, and yield of solids as a function of controlled-release fertilizer (CRF) and planting density (PD) in 2017-18 and $2018-19$.

\begin{tabular}{|c|c|c|c|c|c|c|c|c|}
\hline \multirow[b]{2}{*}{ Treatment } & \multicolumn{2}{|c|}{ Soluble solids content $(\%)$} & \multicolumn{2}{|c|}{ Titratable acidity (\% citric acid) } & \multicolumn{2}{|c|}{ Ratio } & \multicolumn{2}{|c|}{ Yield of solids $\left(\mathrm{kg} \cdot \mathrm{ha}^{-1}\right)$} \\
\hline & $2017-18$ & $2018-19$ & $2017-18$ & 2018-19 & $2017-18$ & 2018-19 & $2017-18$ & 2018-19 \\
\hline $12-3-9$ & $7.68 \pm 0.06 \mathrm{~b}^{\mathrm{y}}$ & $8.07 \pm 0.17$ & $0.99 \pm 0.01$ & $1.10 \pm 0.02$ & $7.82 \pm 0.13$ & $7.40 \pm 0.09$ & $188.24 \pm 17.49 b$ & $187.43 \pm 22.84$ \\
\hline $\mathrm{SR} / \mathrm{LD}$ & $7.67 \pm 0.09 \mathrm{~b}$ & $7.59 \pm 0.15$ & $1.05 \pm 0.02$ & $1.00 \pm 0.02 \mathrm{~b}$ & $7.36 \pm 0.16$ & $7.56 \pm 0.1$ & $125.76 \pm 9.32 \mathrm{c}$ & $103.90 \pm 12.15 \mathrm{~b}$ \\
\hline $\mathrm{SR} / \mathrm{HD}$ & $7.83 \pm 0.11 \mathrm{ab}$ & $8.03 \pm 0.12$ & $1 \pm 0.02$ & $1.02 \pm 0.01 \mathrm{~b}$ & $7.84 \pm 0.06$ & $7.88 \pm 0.15$ & $194.92 \pm 13.51 b$ & $150.88 \pm 17.79 a b$ \\
\hline $\mathrm{DR} / \mathrm{HD}$ & $8.14 \pm 0.06 \mathrm{a}$ & $8.55 \pm 0.23$ & $1 \pm 0.03$ & $1.18 \pm 0.02 \mathrm{a}$ & $8.08 \pm 0.2$ & $7.26 \pm 0.16$ & $360.00 \pm 24.52 \mathrm{a}$ & $245.42 \pm 36.92 \mathrm{a}$ \\
\hline $\mathrm{PD}$ & $0.0177 * *$ & $0.0610^{\mathrm{NS}}$ & $0.5558^{\mathrm{NS}}$ & $0.0001 * * *$ & $0.0945^{\mathrm{NS}}$ & $0.1262^{\mathrm{NS}}$ & $<0.0001 * * *$ & $0.0401 *$ \\
\hline CRF*PD & $0.4239^{\mathrm{NS}}$ & $0.9978^{\mathrm{NS}}$ & $0.6254^{\mathrm{NS}}$ & $0.9162^{\mathrm{NS}}$ & $0.9100^{\mathrm{NS}}$ & $0.9205^{\mathrm{NS}}$ & $0.0546^{\mathrm{NS}}$ & $0.9677^{\mathrm{NS}}$ \\
\hline
\end{tabular}

${ }^{\mathrm{z}} 12 \mathrm{~N}-1.31 \mathrm{P}-7.47 \mathrm{~K}$ and $16 \mathrm{~N}-1.31 \mathrm{P}-16.6 \mathrm{~K}$.

${ }^{\mathrm{y}}$ Means \pm SE $(\mathrm{n}=32)$ followed by different lowercase letters are significantly different at the $P<0.05$ level by Tukey's test.

${ }^{\mathrm{x}} \mathrm{SR} / \mathrm{LD}=$ single row low-density (300 trees per ha). $\mathrm{SR} / \mathrm{HD}=$ single row high-density (440 trees per ha). $\mathrm{DR} / \mathrm{HD}=$ high-density double row staggered in diamond setting ( 975 trees per ha).

NS, * **,***Nonsignificant or significant at $P<0.05,0.01$, or 0.001 , respectively. 


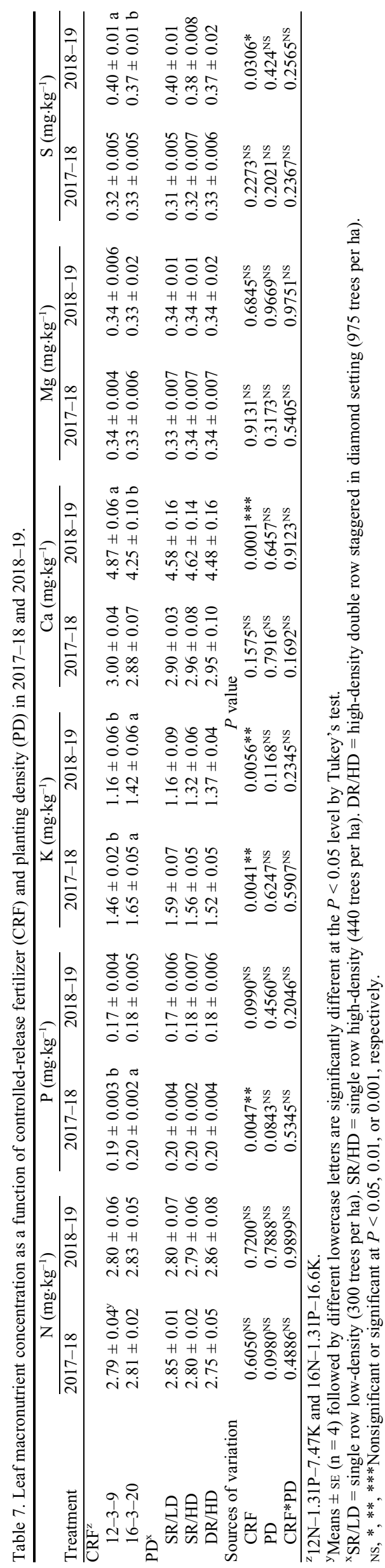

following count categories: $>21$ fruit per carton $(>123 \mathrm{~mm}$ diameter), 27 (123$117 \mathrm{~mm}), 32(117-111 \mathrm{~mm}), 36$ (111$105 \mathrm{~mm}), 40$ (105-100 mm), 48 (100 $95 \mathrm{~mm}), 56(95-90 \mathrm{~mm}), 64(90-84 \mathrm{~mm})$, $<64(<84 \mathrm{~mm})$. Fruit size was used to calculate fruit diameter as follows: (average diameter in each fruit count category $x$ number of fruit in that category) $\div$ total fruit count

To determine fruit yield, fruit from each individual tree per plot was handpicked and weighed using a portable scale (D51P60HR1; Ohaus, Los Angeles, CA). Total fruit yield per ha was calculated by extrapolating fruit yield per tree to area basis.

Fruit quality and yield of solids. For fruit quality determination, 20 uniformsized fruit ranging from 90 to $95 \mathrm{~mm}$ diameter were selected. Fruit were weighed and passed through a juice press (model 2720; Brown International Corporation, Covina, CA). Juice volume and juice weight were recorded. Soluble solids content of the juice was measured using a refractometer (HI96801; Hanna Instruments, Woonsocket, RI). A pipette was used to deliver two to three drops of juice in the clean glass measuring surface of the refractometer. Fruit acidity was measured with an automatic potentiometric titrator (HI931; Hanna Instruments, Woonsocket, RI). For titration, $25 \mathrm{~mL}$ of sample juice was diluted with deionized water to make $50 \mathrm{~mL}$. The solution was later titrated using a $1 \mathrm{~N}$ sodium hydroxide solution. Fruit quality was also expressed as the ratio of soluble solids content and titratable acidity. Juice yield was calculated and expressed as yield of solids per ha by the equation: [ $(\%$ juice in fruit $\div 100) \times($ soluble solids content $\div$ 100) $\times$ fruit yield] (Ferrarezi et al., 2019).

Leaf nutrient concentration. Leaf samples were collected in August to determine leaf nutrient concentrations. Fully expanded, mature leaves were collected with the leaf petiole attached, avoiding young, diseased, insect-damaged, mechanically injured, or dead leaves (Morgan and Kadyampakeni, 2020). Eight random trees were chosen excluding border trees to collect leaf samples. The samples were preserved in a cooler during the sampling period and were acid-washed before analysis. Samples were placed in an oven at $80^{\circ} \mathrm{C}$ overnight to dry. The dried samples from each plot were ground to pass a 1-mm mesh screen (Wiley Laboratory Mill Model 4 3375-E10; Thomas Scientific, Swedesboro, NJ). Five grams of leaf sample were analyzed using the dry-ashing method and assessed by inductively coupled plasma atomic emission spectroscopy to determine the concentration of $\mathrm{P}, \mathrm{K}$, calcium $(\mathrm{Ca})$, Magnesium $(\mathrm{Mg}), \mathrm{S}$, boron $(\mathrm{B})$, copper $(\mathrm{Cu}), \mathrm{Fe}, \mathrm{Mn}$, and $\mathrm{Zn}$. Leaf $\mathrm{N}$ concentration was measured by macro dry combustion using a LECO CNS-2000 analyzer (LECO Corporation, St. Joseph, MI)

Soil nutrient concentration. Samples were collected before fertilization in Febru- ary $\approx 60 \mathrm{~cm}$ away from the trunk in the area wetted by the microsprinkler for maximum root activity as recommended by Morgan and Kadyampakeni (2020). One 20-cm-deep soil core per tree was taken in 15 locations per plot. The subsamples were thoroughly mixed to get a representative composite sample. Soil samples were analyzed by Mehlich 3 acid extraction (Morgan and Kadyampakeni, 2020) to determine extractable $\mathrm{P}, \mathrm{K}, \mathrm{Ca}$, and $\mathrm{Mg}$ along with $\mathrm{S}$, $\mathrm{B}, \mathrm{Cu}, \mathrm{Fe}, \mathrm{Mn}$, and $\mathrm{Zn}$ using $0.2 \mathrm{M} \mathrm{CH} 3 \mathrm{COOH}$, 0.015 M NH4F, 0.013 M HNO3, $0.001 \mathrm{M}$ ethylenediaminetetraacetic, and $0.25 \mathrm{M}$ NH4NO3. For soil $\mathrm{pH}$ determination, $25 \mathrm{~g}$ of homogeneous soil samples were mixed with 25 $\mathrm{mL}$ of deionized water (Schofield and Taylor, 1955).

Statistical analysis. Data were analyzed by year for two consecutive seasons (201718 and 2018-19) using SAS 9.4 (SAS Institute, Cary, NC). A generalized linear mixed model was used to analyze error variance, with treatments entered as fixed effects and block as a random effect. The data were checked for assumptions of the linear model. Log transformation and square root transformation was executed as needed. Data were subjected to analysis of variance by the $\mathrm{F}$ test and, when significant, multiple comparisons were assessed by Tukey's post hoc honest significant difference test $(P \leq 0.05)$.

\section{Results and Discussion}

Concentration of CLas DNA on plant leaf tissue. All sampled trees were infected by $C$ Las with visible HLB symptoms such as loss of foliage, fruit drop, and tree death. $\mathrm{Ct}$ values of $C$ Las DNA were lower than 32 in all treatments during the experimental period with no statistical differences among treatments (Table 3), indicating all the sampled trees were affected by HLB (Albrecht and Bowman, 2011; Shin and van Bruggen, 2018). There was a significant interaction between planting density and the CRF blends $(P=0.0013)$ in 2018-19 (Fig. 2), but the Ct values were also lower than 32 . These results indicate that application of nutritional treatments alone or in combination with planting density does not provide a therapeutic effect on CLas-infected grapefruit trees.

Our study indicated no effect of planting density alone on $\mathrm{Ct}$ value of CLas DNA. Recently, Moreira et al. (2019) observed high-density planting resulted in lower HLB incidence in sweet oranges, indicating those trees might have an advantage caused by a lower psyllid-to-plant ratio compared with low-density plantings. High-density plantings may dilute psyllid populations, resulting in lower disease incidence. However, that was not the case with grapefruit in this study.

There is limited research on the effects of higher than recommended micronutrient rates on $\mathrm{Ct}$ values in HLB-affected grapefruit, especially Mn. Recently, Zambon et al. (2019) showed that soil application of $\mathrm{Mn}$ at $4 \times$ the recommended rate increased the $\mathrm{Ct}$ value of HLB-affected 'Vernia' sweet orange and suggested that elevated application of Mn could be toxic to CLas but not 


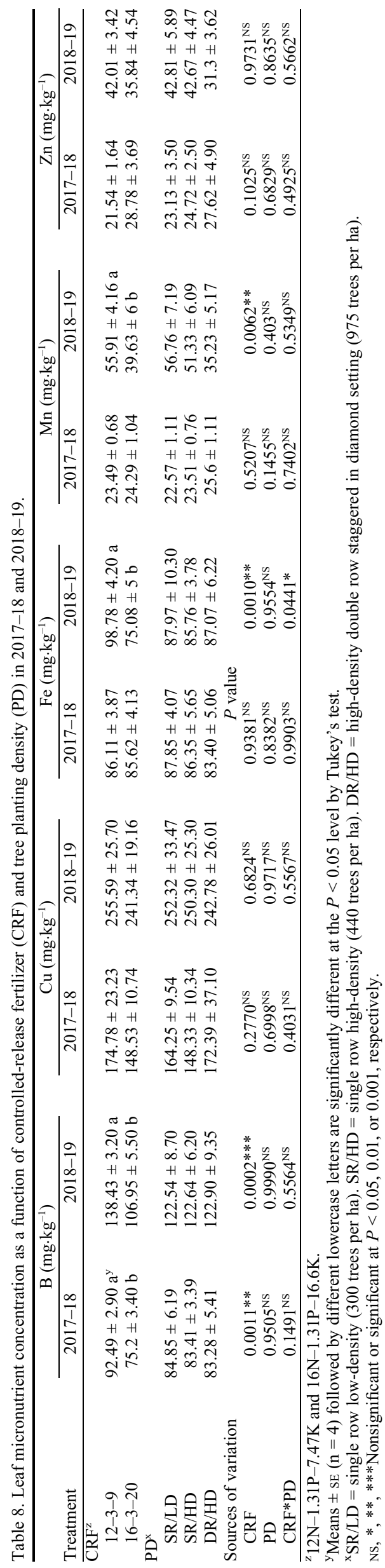

to the tree. We did not observe a similar effect when $\mathrm{Mn}$ was applied at higher rate along with $\mathrm{B}$ over two growing seasons. In the present study, the lack of micronutrient effects may be because HLB induces loss of fibrous roots, which ultimately results in lower nutrient uptake by trees.

Tree growth. Canopy volume was affected by planting density, and decreased as planting density increased (Table 4; $P<$ $0.0001)$. In 2017-18, canopy volume was $28 \%$ lower in DR/HD planting than in other treatments. In 2018-19, canopy volume in $\mathrm{DR} / \mathrm{HD}$ planting was $28 \%$ and $33 \%$ lower than SR/HD and SR/LD plantings, respectively. Similarly, trunk diameter was also affected by planting density (Table $4 ; P<$ 0.0001 ). In 2017-18, trunk diameter was $11 \%$ lower in $\mathrm{DR} / \mathrm{HD}$ planting than in other treatments. In 2018-19, trunk diameter in DR/HD planting was $13 \%$ and $17 \%$ lower than in SR/HD and in SR/LD planting densities, respectively.

Our study showed that high-density planting affected tree growth, which was expected due to greater competition between trees at high density for available resources, such as water and solar radiation. A study conducted by Zaman and Schumann (2005) measuring canopy volume of 'Valencia' sweet orange manually and using an ultrasonic device indicated greater canopy growth in widely spaced trees. In our study, canopy volume was also $10 \%$ higher in 2017-18 and 9\% higher in 201819 using $12 \mathrm{~N}-1.31 \mathrm{P}-7.47 \mathrm{~K}$ compared with the $16 \mathrm{~N}-1.31 \mathrm{P}-16.6 \mathrm{~K}$, but trunk diameter was unaffected (Table 4). Our results also showed that the $12 \mathrm{~N}-1.31 \mathrm{P}-7.47 \mathrm{~K}$ blend with $\mathrm{N}: \mathrm{K}$ ratio of 1:0.75 along with higher micronutrients resulted in greater canopy volume than the $16 \mathrm{~N}-1.31 \mathrm{P}-16.6 \mathrm{~K}$ with $\mathrm{N}: \mathrm{K}$ ratio of $1: 1.25$ (Table 2). Alva et al. (2006) and Morgan and Kadyampakeni (2020) suggested that an $\mathrm{N}$ and $\mathrm{K}$ ratio of $1: 1$ results in better citrus tree growth, fruit yield, and fruit quality. Ranade-Malvi (2011) suggested that $K$ has a direct synergistic relationship with several micronutrients such as Fe, Mn, and B. Our study suggests that increasing micronutrient application in tandem with decreasing the amount of K applied (by using the $12 \mathrm{~N}-$ 1.31P-7.47K + micros blend) can lead to greater canopy volume (Table 4).

Fruit number, size, and yield. Fruit diameter did not differ among treatments (Table 5). Fruit yield was 30\% lower in 2018-19 compared with 2017-18 due to hurricane Irma, which hit Florida in Sept. 2017. Hurricanes and tropical storms in Florida can cause fruit damage and drop, along with a deterioration in orchard health for several seasons, by spreading pests and diseases (Ferrarezi et al., 2020). In 2017$18, \mathrm{DR} / \mathrm{HD}$ planting resulted in the lowest fruit yield per tree, with SR/HD $(13.19 \mathrm{~kg} /$ tree) presenting yield $28 \%$ higher than DR/ HD planting $(10.27 \mathrm{~kg} /$ tree) (Table $5 ; P<$ $0.05)$. In the following year, fruit yield per tree was the same for all planting densities tested (Table 5; $P>0.05$ ). The DR/HD produced the greatest fruit yield per area $\left(9968 \mathrm{~kg} \cdot \mathrm{ha}^{-1}\right)$. The SR/HD and SR/LD produced $43 \%$ and $62 \%$ less fruit per area than DR/HD planting (Table 5). In 2018-19, DR/ HD produced the highest fruit yield per area $\left(6886 \mathrm{~kg} \cdot \mathrm{ha}^{-1}\right)$. The SR/LD planting produced $62 \%$ lower fruit yield per area than DR/HD (Table 5).

Several studies have suggested that highdensity planting of citrus induces greater fruit yield by increasing groundcoverage and optimizing water and nutrient utilization without compromising fruit quality (Dalal et al., 2013; Moreira et al., 2019; Phuyal et al., 2020; Singerman et al., 2018). High-density planting is a practical way to increase fruit yield under HLB-endemic conditions. Trees affected by HLB require smaller space due to lower canopy volume (Bowman et al., 2016) and less fibrous roots compared with healthy trees (Graham et al., 2013).

In 2017-18, the blend with higher $\mathrm{K}$ $(16 \mathrm{~N}-1.31 \mathrm{P}-16.6 \mathrm{~K})$ resulted in more fruit per tree, $30 \%$ higher yield per tree, and $32 \%$ more fruit yield. There were no interactions between CRF blends and planting densities (Table 5). High micronutrient application rates along with lower $\mathrm{K}$ did not increase fruit yield and yield of solids, indicating increasing soil application of higher micronutrients may not contribute to higher fruit yield in grapefruit affected by HLB.

Previous studies concluded that canopy volume is directly correlated to fruit yield. Levy et al. (1978) observed that an increase in canopy volume resulted in higher grapefruit fruit yield, possibly due to the increase in photosynthetic area. However, our study only showed relationship between canopy volume and fruit yield in HLB-affected grapefruit in the first season (Tables 4 and 5).

Fruit quality and yield of solids. The soluble solids content was affected by treatments only in 2017-18. Fruit produced under DR/HD planting density induced $6 \%$ higher soluble solids than under SR/LD. Fruit acidity was only affected by planting density in 2018-19. Fruit from DR/HD planting was $16 \%$ more acidic (titratable acidity $1.16 \%$ ) than in other treatments. In 2017-18, DR/HD had the greatest yield of solids $\left(360 \mathrm{~kg} \cdot \mathrm{ha}^{-1}\right)$, whereas SR/HD and SR/LD produced $46 \%$ and $65 \%$ less yield of solids, respectively, than DR/HD planting. In 2018-19, DR/HD had the greatest yield of solids $\left(245 \mathrm{~kg} \cdot \mathrm{ha}^{-1}\right)$. The SR/LD produced $65 \%$ lower yield of solids than DR/HD (Table 6).

We observed that grapefruit grown under high-density planting resulted in greater fruit soluble solids content. This might be caused by greater competition for water, which increases deposition of sugars from changes in fruit water content and osmotic adjustment. Although the role of abiotic stresses in the synthesis of soluble sugars in citrus is unclear, stress may influence production of hormones such as abscisic acid and ethylene, which can alter the sugar sensing mechanism (Rosa et al., 2009). García-Tejero et al. (2010) speculated that water stress in sweet 
Table 9. Soil pH, cation exchange capacity (CEC), and soil macronutrient concentration as a function of controlled-release fertilizer (CRF) and tree planting density (PD) in 2018-19.

\begin{tabular}{|c|c|c|c|c|c|c|c|}
\hline Treatment & Soil pH & $\operatorname{CEC~}\left(\mathrm{cmol}_{\mathrm{c}} \cdot \mathrm{kg}^{-1}\right)$ & $\mathrm{P}\left(\mathrm{mg} \cdot \mathrm{kg}^{-1}\right)$ & $\mathrm{K}\left(\mathrm{mg} \cdot \mathrm{kg}^{-1}\right)$ & $\mathrm{Ca}\left(\mathrm{mg} \cdot \mathrm{kg}^{-1}\right)$ & $\mathrm{Mg}\left(\mathrm{mg} \cdot \mathrm{kg}^{-1}\right)$ & $\mathrm{S}\left(\mathrm{mg} \cdot \mathrm{kg}^{-1}\right)$ \\
\hline \multicolumn{8}{|l|}{$\overline{\mathrm{CRF}^{\mathrm{z}}}$} \\
\hline $12-3-9$ & $6.00 \pm 0.12 b^{y}$ & $3.03 \pm 0.06$ & $15.88 \pm 1.06$ & $20.29 \pm 1.75$ & $350.92 \pm 20.37$ & $19.29 \pm 1.03 b$ & $18.08 \pm 2.40$ \\
\hline $16-3-20$ & $6.38 \pm 0.12 \mathrm{a}$ & $3.19 \pm 0.26$ & $13.67 \pm 1.50$ & $21.00 \pm 1.46$ & $422.13 \pm 56.55$ & $24.08 \pm 1.20 \mathrm{a}$ & $13.75 \pm 2.07$ \\
\hline \multicolumn{8}{|l|}{$\mathrm{PD}^{\mathrm{x}}$} \\
\hline $\mathrm{SR} / \mathrm{LD}$ & $6.00 \pm 0.19$ & $3.23 \pm 0.36$ & $16.44 \pm 1.74$ & $19.25 \pm 1.51$ & $403.06 \pm 89.50$ & $20.38 \pm 1.42$ & $15.19 \pm 3.20$ \\
\hline $\mathrm{SR} / \mathrm{HD}$ & $6.40 \pm 0.12$ & $3.04 \pm 0.17$ & $14.31 \pm 1.33$ & $21.25 \pm 2.11$ & $379.88 \pm 28.36$ & $23.25 \pm 2.26$ & $15.38 \pm 2.73$ \\
\hline $\mathrm{DR} / \mathrm{HD}$ & $6.17 \pm 0.13$ & $3.06 \pm 0.06$ & $13.56 \pm 1.75$ & $21.44 \pm 2.28$ & $376.63 \pm 13.73$ & $21.44 \pm 0.79$ & $17.19 \pm 2.76$ \\
\hline Sources of variation & & & & $P$ value & & & \\
\hline $\mathrm{CRF}$ & $0.0268 *$ & $0.6867^{\mathrm{NS}}$ & $0.2848^{\mathrm{NS}}$ & $0.7487^{\mathrm{NS}}$ & $0.3303^{\mathrm{NS}}$ & $0.0387^{*}$ & $0.2279^{\mathrm{NS}}$ \\
\hline PD & $0.1489^{\mathrm{NS}}$ & $0.9322^{\mathrm{NS}}$ & $0.4772^{\mathrm{NS}}$ & $0.7572^{\mathrm{NS}}$ & $0.9692^{\mathrm{NS}}$ & $0.3422^{\mathrm{NS}}$ & $0.8748^{\mathrm{NS}}$ \\
\hline $\mathrm{CRF}^{*} \mathrm{PD}$ & $0.4637^{\mathrm{NS}}$ & $0.8046^{\mathrm{NS}}$ & $0.7412^{\mathrm{NS}}$ & $0.7000^{\mathrm{NS}}$ & $0.7102^{\mathrm{NS}}$ & $0.4946^{\mathrm{NS}}$ & $0.4139^{\mathrm{NS}}$ \\
\hline
\end{tabular}

$\mathrm{z} 12 \mathrm{~N}-1.31 \mathrm{P}-7.47 \mathrm{~K}$ and $16 \mathrm{~N}-1.31 \mathrm{P}-16.6 \mathrm{~K}$.

${ }^{\mathrm{y}}$ Means $\pm \mathrm{SE}(\mathrm{n}=4)$ followed by different lowercase letters are significantly different at the $P<0.05$ level by Tukey's test.

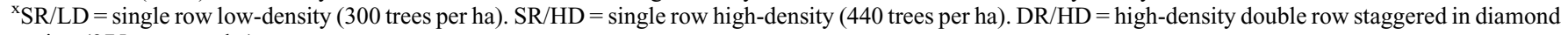
setting (975 trees per ha).

Ns, $* * *, * * *$ Nonsignificant or significant at $P<0.05,0.01$, or 0.001 , respectively.

Table 10. Soil micronutrient concentration as a function of controlled-release fertilizer (CRF) and tree planting density (PD) in $2018-19$.

\begin{tabular}{|c|c|c|c|c|c|}
\hline Treatment & $\mathrm{B}\left(\mathrm{mg} \cdot \mathrm{kg}^{-1}\right)$ & $\mathrm{Cu}\left(\mathrm{mg} \cdot \mathrm{kg}^{-1}\right)$ & $\mathrm{Fe}\left(\mathrm{mg} \cdot \mathrm{kg}^{-1}\right)$ & $\operatorname{Mn}\left(\mathrm{mg} \cdot \mathrm{kg}^{-1}\right)$ & $\mathrm{Zn}\left(\mathrm{mg} \cdot \mathrm{kg}^{-1}\right)$ \\
\hline \multicolumn{6}{|l|}{$\overline{\mathrm{CRF}^{\mathrm{z}}}$} \\
\hline $12-3-9$ & $0.19 \pm 0.01 b^{y}$ & $13.52 \pm 0.56$ & $8.33 \pm 0.74$ & $4.96 \pm 0.42 \mathrm{a}$ & $9.81 \pm 0.61$ \\
\hline $16-3-20$ & $0.38 \pm 0.07 \mathrm{a}$ & $14.07 \pm 0.70$ & $8.83 \pm 0.84$ & $2.42 \pm 0.19 \mathrm{~b}$ & $9.78 \pm 0.91$ \\
\hline \multicolumn{6}{|l|}{$\mathrm{PD}^{\mathrm{x}}$} \\
\hline $\mathrm{SR} / \mathrm{LD}$ & $0.31 \pm 0.11$ & $13.95 \pm 0.83$ & $9.19 \pm 0.85$ & $4.13 \pm 0.81$ & $10.09 \pm 1.16$ \\
\hline $\mathrm{SR} / \mathrm{HD}$ & $0.25 \pm 0.02$ & $13.74 \pm 0.48$ & $9.75 \pm 0.89$ & $3.38 \pm 0.43$ & $9.31 \pm 0.93$ \\
\hline $\mathrm{DR} / \mathrm{HD}$ & $0.29 \pm 0.05$ & $13.69 \pm 1.00$ & $6.81 \pm 0.88$ & $3.56 \pm 0.55$ & $9.99 \pm 0.76$ \\
\hline Sources of variation & & & $P$ value & & \\
\hline CRF & $0.0149 *$ & $0.5500^{\mathrm{NS}}$ & $0.6862^{\mathrm{NS}}$ & $0.0062 * *$ & $0.9731^{\mathrm{NS}}$ \\
\hline PD & $0.7541^{\mathrm{NS}}$ & $0.9800^{\mathrm{NS}}$ & $0.0757^{\mathrm{NS}}$ & $0.4030^{\mathrm{NS}}$ & $0.8635^{\mathrm{NS}}$ \\
\hline $\mathrm{CRF}^{*} \mathrm{PD}$ & $0.2282^{\mathrm{NS}}$ & $0.9548^{\mathrm{NS}}$ & $0.6930^{\mathrm{NS}}$ & $0.5349^{\mathrm{NS}}$ & $0.5662^{\mathrm{NS}}$ \\
\hline
\end{tabular}

${ }^{\mathrm{z}} 12 \mathrm{~N}-1.31 \mathrm{P}-7.47 \mathrm{~K}$ and $16 \mathrm{~N}-1.31 \mathrm{P}-16.6 \mathrm{~K}$.

${ }^{\mathrm{y}}$ Means $\pm \mathrm{SE}(\mathrm{n}=4)$ followed by different lowercase letters are significantly different at the $P<0.05$ level by Tukey's test.

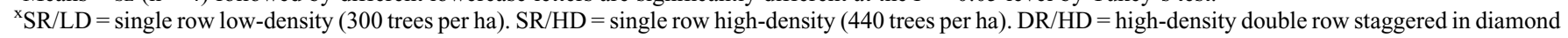
setting (975 trees per ha).

NS, *,**,***Nonsignificant or significant at $P<0.05,0.01$, or 0.001 , respectively.

orange influences organoleptic fruit parameters, such as total soluble solids and total acidity with low influence in morphological variables such as fruit weight, equatorial diameter, or peel thickness. Hutton and Loveys (2011) suggested that reduction in water input due to partial root zone drying in navel orange resulted in significant reductions in the percent juice and an increase in percent acid without changing sugar content.

In our study, there were only differences in the effect of CRF blends on soluble solids content in 2017-18 (Table 6; $P=0.0038$ ). The use of $16 \mathrm{~N}-1.31 \mathrm{P}-16.6 \mathrm{~K}$ resulted in greater soluble solids content and greater yield of solids than $12 \mathrm{~N}-1.31 \mathrm{P}-7.47 \mathrm{~K}$. Juice obtained from $16 \mathrm{~N}-1.31 \mathrm{P}-16.6 \mathrm{~K}$ had $5 \%$ higher soluble solids than $12 \mathrm{~N}-1.31 \mathrm{P}-$ $7.47 \mathrm{~K}$, possibly because $16 \mathrm{~N}-1.31 \mathrm{P}-16.6 \mathrm{~K}$ contained higher $\mathrm{K}$ levels $\left(225 \mathrm{~kg} \cdot \mathrm{ha}^{-1}\right)$ than $12 \mathrm{~N}-1.31 \mathrm{P}-7.47 \mathrm{~K} \quad\left(135 \mathrm{~kg} \cdot \mathrm{ha}^{-1}\right)$. Obreza (2003) similarly observed application of $225 \mathrm{~kg} \cdot \mathrm{ha}^{-1}$ of $\mathrm{K}$ in grapefruit resulted in higher soluble solids content and higher number of fruit, although that study was conducted before the HLB era in Florida.

As an industry standard, the higher the soluble solids to acid ratio, the greater the fruit grade. The USDA classifies three grades of grapefruit based on fruit quality: U.S. Grades A, B, and Substandard. Grades A and $\mathrm{B}$ are further classified into two cate- gories: unsweetened and sweetened based on soluble solids to acid ratio. The minimum ratio unsweetened for grade $B$ is $7: 1$ and the maximum ratio sweetened for grade $\mathrm{A}$ is $14: 1$ (USDA, 2012). The ratio in this study remained the same with the application of the different treatments.

Leaf nutrient concentration. Leaf nutrient concentration varied by year (Tables 7 and 8). Planting density did not affect nutrient concentration $(P>0.05)$. In $2017-18,16 \mathrm{~N}-1.31 \mathrm{P}-$ $16.6 \mathrm{~K}$ resulted in higher leaf $\mathrm{K}$ and $\mathrm{P}$ concentrations. In 2018-19, 16N-1.31P-16.6K resulted in higher leaf $\mathrm{K}$ concentration and lower $\mathrm{Ca}, \mathrm{Fe}$, $\mathrm{Mn}$, and $\mathrm{S}$ concentrations. The leaf $\mathrm{B}$ concentration was higher in trees treated with $12 \mathrm{~N}$ 1.31P-7.47K in both 2017-18 and 2018-19.

In $2017-18,16 \mathrm{~N}-1.31 \mathrm{P}-16.6 \mathrm{~K}$ resulted in higher leaf $\mathrm{P}$ concentration, possibly due to an interaction between soil $\mathrm{pH}$ (Table 9) and nutrient availability because $16 \mathrm{~N}-1.31 \mathrm{P}-$ $16.6 \mathrm{~K}$ resulted in $\mathrm{pH}$ values closer to neutral than $12 \mathrm{~N}-1.31 \mathrm{P}-7.47 \mathrm{~K}$, which could have facilitated greater $\mathrm{P}$ uptake. The B concentration was higher in trees treated with $12 \mathrm{~N}-$ $1.31 \mathrm{P}-7.47 \mathrm{~K}$ during the study because this blend contained higher B. Kadyampakeni (2019) also observed a linear increase in leaf $\mathrm{B}$ concentration during fall with an increase in B application rate. Foliar nutrient concentrations were compared against the optimal values based on Koo et al. (1984). In 2017-
18, we found that leaf $\mathrm{Mn}$ and $\mathrm{Zn}$ concentrations were deficient in some treatments $(<25$ $\mathrm{mg} \cdot \mathrm{kg}^{-1}$ ). Additionally, in 2018-19, B was above sufficiency range in plant tissue $(>120$ $\mathrm{mg} \cdot \mathrm{kg}^{-1}$ ) except at $16 \mathrm{~N}-1.31 \mathrm{P}-16.6 \mathrm{~K}$ blend. Further, the concentration of $\mathrm{Cu}$ was consistently high $\left(>20 \mathrm{mg} \cdot \mathrm{kg}^{-1}\right)$ due to frequent application of copper-based fungicides to control citrus canker (Xanthomonas axonopodis pv. citri).

Soil nutrient concentration. Planting density did not affect soil nutrient concentrations overtime. Furthermore, there was no interaction between planting density and CRF blends (Tables 9 and 10). The use of $16 \mathrm{~N}-$ $1.31 \mathrm{P}-16.6 \mathrm{~K}$ increased soil $\mathrm{pH}$ and soil $\mathrm{Mg}$ and $\mathrm{B}$ concentrations but decreased Mn concentration. Cation exchange capacity was similar for both treatments. Higher soil $\mathrm{pH}$ in $16 \mathrm{~N}-1.31 \mathrm{P}-16.6 \mathrm{~K}$ blend was possibly due to the presence of alkaline materials in the formulation. Our results were similar to McCauley et al. (2009), who reported soil $\mathrm{pH}$ was greatly influenced by base- and acidforming ions in the soil. Although soil $\mathrm{pH}$ was in the optimal range for nutrient availability, soil $\mathrm{P}$ and $\mathrm{Mg}$ were below the sufficiency range reported by Morgan and Kadyampakeni (2020) despite the fact the research area soil is calciferous and fertilizer $\mathrm{S}$ concentration may have contributed to $\mathrm{pH}$ reduction. According to Shober et al. (2018), 
elemental application of S may temporarily lower soil $\mathrm{pH}$ in alkaline soil.

\section{Conclusions}

Our study showed that high-density planting affected tree growth, resulting in smaller trunk diameter and lower canopy volume per tree. High-density planting also resulted in greater fruit yield and yield of solids per area. Fruit produced at high-density planting tended to increase the soluble solids content. The use of fertilizer blends, regardless of the $\mathrm{N}$ to $\mathrm{K}$ ratio and with higher sulfur-coated micronutrient content, did not change the $\mathrm{Ct}$ value in grapefruit. Increased micronutrient application resulted in higher canopy volume without contributing to fruit quality. Highdensity staggered planting appears to be a good strategy for grapefruit production under HLB-endemic conditions. However, the cost for weed control and long-term effects of high-density planting still need to be accessed before commercial recommendations. Further nutritional studies for multiple successive growing seasons and using other rootstocks are necessary to expand the understanding of enhanced nutritional treatments on HLB-affected grapefruit.

\section{Literature Cited}

Albrecht, U. and K.D. Bowman. 2011. Tolerance of the trifoliate citrus hybrid US-897 (Citrus reticulata Blanco $\times$ Poncirus trifoliata $\mathrm{L}$. Raf.) to Huanglongbing. HortScience 46:16-22.

Alva, A.K., S. Paramasivam, T.A. Obreza, and A.W. Schumann. 2006. Nitrogen best management practice for citrus trees: I. Fruit yield, quality, and leaf nutritional status. Scientia Hort. 107:233-244.

Bowman, K.D., G. McCollum, and U. Albrecht. 2016. Performance of 'Valencia' orange (Citrus sinensis [L.] Osbeck) on 17 rootstocks in a trial severely affected by Huanglongbing. Scientia Hort. 201:355-361.

Castle, W.S., K.D. Bowman, J.W. Grosser, R.S. Ferrarezi, S.H. Futch, and S. Rogers. 2019. Florida citrus rootstock selection guide, 4 th ed. SP248. Univ. of Florida IFAS, Gainesville. 20 Jan. 2020. $<$ https://edis.ifas.ufl.edu/pdffiles/ HS/HS126000.pdf>.

Dalal, R.P.S., A.K. Sangwan, B.S. Beniwal, and S. Sharma. 2013. Effect of planting density on canopy parameter, yield, and water use efficiency of Kinnow mandarin. Indian J. Hort. 70:587-590.

Farnsworth, D., K.A. Grogan, A.H. van Bruggen, and C.B. Moss. 2014. The potential economic cost and response to greening in Florida citrus. Choices 29:1-6.

Ferrarezi, R.S., J.A. Qureshi, A.L. Wright, M.A. Ritenour, and N.P. Macan. 2019. Citrus production under screen as a strategy to protect grapefruit trees from Huanglongbing disease. Front. Plant Sci. 10:1598.

Ferrarezi, R.S., K. Rodriguez, and D. Sharp. 2020. How historical trends in Florida all-citrus production correlate with devastating hurricane and freeze events. Weather 75:77-83.

García-Tejero, I., J.A. Jiménez-Bocanegra, G. Martínez, R. Romero, V.H. Durán-Zuazo, and J.L. Muriel-Fernández. 2010. Positive impact of regulated deficit irrigation on yield and fruit quality in a commercial citrus orchard [Citrus sinensis (L.) Osbeck, cv. salustiano]. Agr. Water Mgt. 97:614-622.

Gottwald, T.R., J.H. Graham, M.S. Irey, T.G. McCollum, and B.W. Wood. 2012. Inconsequential effect of nutritional treatments on Huanglongbing control, fruit quality, bacterial titer, and disease progress. J. Crop Prot. 36:7382.

Graham, J.H., E.G. Johnson, T.R. Gottwald, and M.S. Irey. 2013. Presymptomatic fibrous root decline in citrus trees caused by Huanglongbing and potential interaction with Phytophthora spp. Plant Dis. 97:1195-1199.

Halbert, S.E. and K.L. Manjunath. 2004. Asian citrus psyllids (Sternorrhyncha: Psyllidae) and greening disease of citrus: A literature review and assessment of risk in Florida. Fla. Entomol. 87:330-353.

Hutton, R.J. and B.R. Loveys. 2011. A partial root zone drying irrigation strategy for citrus-effects on water use efficiency and fruit characteristics. Agr. Water Mgt. 98:1485-1496.

Irfan, S.A., R. Razali, K. KuShaari, N. Mansor, B. Azeem, and A.N.F. Versypt. 2018. A review of mathematical modeling and simulation of controlled-release fertilizers. J. Control. Release 271:45-54.

Johnson, E.G., J. Wu, D.B. Bright, and J.H. Graham. 2014. Association of 'Candidatus Liberibacter asiaticus' root infection, but not phloem plugging with root loss on Huanglongbingaffected trees prior to appearance of foliar symptoms. Plant Pathol. 63:290-298.

Kadyampakeni, D.M. 2019. Interaction of soil boron application with leaf B concentration, root length density, and canopy size of citrus affected by Huanglongbing. J. Plant Nutr. 43:186-193.

Kadyampakeni, D.M., K.T. Morgan, P. NkediKizza, and G.N. Kasozi. 2015. Nutrient management options for Florida citrus: A review of NPK application and analytical methods. J. Plant Nutr. 38:568-583.

Koo, R.C.J., C.A. Anderson, I. Stewart, D.P.H Tucker, D.V. Calvert, and H.K. Wutscher. 1984. Recommended fertilizers and nutritional sprays for citrus. Florida Agricultural Expt. Sta. Bul. 536D.

Levy, Y., H. Bielorai, and J. Shalhevet. 1978. Long-term effects of different irrigation regimes on grapefruit tree development and yield. J. Amer. Soc. Hort. Sci. 103:680-683.

Li, J., L. Li, Z. Pang, V.G. Kolbasov, R. Ehsani, E.W. Carter, and N. Wang. 2019. Developing citrus Huanglongbing (HLB) management strategies based on the severity of symptoms in HLB-endemic citrus-producing regions. Phytopathology 109:582-592.

Li, W., J.S. Hartung, and L. Levy. 2006. Quantitative real-time PCR for detection and identification of Candidatus Liberibacter species associated with citrus Huanglongbing. J. Microbiol. Methods 66:104-115.

McCauley, A., C. Jones, and J. Jacobsen. 2009. Soil $\mathrm{pH}$ and organic matter. Nutr. Mgt. Module 8: 1-12. <https://certifiedcropadviser.org/files/ certifications/certified/education/self-study/exampdfs/38.pdf $>$.

Moreira, A.S., E.S. Stuchi, P.R.B. Silva, R.B. Bassanezi, E.A. Girardi, and F.F. Laranjeira. 2019. Could tree density play a role in managing citrus Huanglongbing epidemics? Trop. Plant Pathol. 44:268-274.

Morgan, K.T. and D.M. Kadyampakeni. 2020. Nutrition of Florida citrus trees. 3rd ed. SL 253. Univ. of Florida IFAS, Gainesville. 5 May 2020. $<$ http://edis.ifas.ufl.edu/pdffiles/SS/SS47800. pdf $>$.
Morgan, K.T., K.E. Cushman, and S. Sato. 2009. Release mechanisms for slow-and controlledrelease fertilizers and strategies for their use in vegetable production. HortTechnology 19:10 12.

Morgan, K.T., R.E. Rouse, and R.C. Ebel. 2016. Foliar applications of essential nutrients on growth and yield of 'Valencia' sweet orange infected with Huanglongbing. HortScience 51:1482-1493.

Obreza, T.A. 2003. Importance of potassium in a Florida citrus nutrition program. Better Crop. 87:60-63. <https://ucanr.edu/sites/nm/files/ 76669.pdf $>$.

Obreza, T.A. and R.E. Rouse. 1993. Fertilizer effects on early growth and yield of Hamlin orange trees. HortScience 28:111-114.

Obreza, T.A., R.E. Rouse, and J.B. Sherrod. 1999. Economics of controlled-release fertilizer use on young citrus trees. J. Prod. Agr. 12:69-73.

Obreza, T.A. and J.B. Sartain. 2010. Improving nitrogen and phosphorus fertilizer use efficiency for Florida's horticultural crops. HortTechnology 20:23-33.

Obreza, T.A., R. Rouse, and E.A. Hanlon. 2006. Advancements with controlled-release fertilizers for Florida citrus production: 1996-2006. SL-243. Univ. of Florida IFAS, Gainesville. 20 Jan. 2020. <https://ucanr.edu/sites/nm/files/76682. pdf $>$.

Phuyal, D., T.A.R. Nogueira, A.D. Jani, D.M. Kadyampakeni, K.T. Morgan, and R.S. Ferrarezi. 2020. 'Ray Ruby' grapefruit affected by Huanglongbing II. Planting density, soil, and foliar nutrient management. HortScience, doi: 10.21273/HORTSCI15255-20.

Ranade-Malvi, U. 2011. Interaction of micronutrients with major nutrients with special reference to potassium. Karnataka J. Agr. Sci. 24:106-109.

Rosa, M., C. Prado, G. Podazza, R. Interdonato, J.A. González, M. Hilal, and F.E. Prado. 2009 Soluble sugars - metabolism, sensing and abiotic stress a complex network in the life of plants. Plant Signal. Behav. 4:388-393.

Schofield, R.K. and A.W. Taylor. 1955. The measurement of soil pH. Soil Sci. Soc. Amer. J. 19:164-167.

Shin, K. and A.H.C. van Bruggen. 2018. Bradyrhizobium isolated from Huanglongbing (HLB) affected citrus trees reacts positively with primers for Candidatus Liberibacter asiaticus. Eur. J. Plant Pathol. 151:291-306.

Shober, A.L., C. Wiese, G.C. Denny, and R. Mylavarapu. 2018. Soil pH and the home landscape or garden. SL 256. Univ. of Florida IFAS, Gainesville. 20 Jan. 2020. <https://edis. ifas.ufl.edu/pdffiles/SS/SS48000.pdf>.

Singerman, A., M. Burani-Arouca, and S.H. Futch. 2018. The profitability of new citrus plantings in Florida in the era of Huanglongbing. HortScience 53:1655-1663.

Spyke, P., J. Sherrod, and J. Grosser. 2017. Controlled-release fertilizer boosts health of HLB trees. Citrus Ind. (April), Part 1. 20 Jan. 2020. <https://crec.ifas.ufl.edu/extension/trade_ journals/2017/2017_April_boosts.pdf>.

Stansly, P.A., H.A. Arevalo, J.A. Qureshi, M.M. Jones, K. Hendricks, P.D. Roberts, and F.M. Roka. 2014. Vector control and foliar nutrition to maintain economic sustainability of bearing citrus in Florida groves affected by Huanglongbing. Pest Mgt. Sci. $70: 415-426$

Tansey, J.A., P. Vanaclocha, C. Monzo, M. Jones, and P.A. Stansly. 2017. Costs and benefits of insecticide and foliar nutrient applications to 
Huanglongbing-infected citrus trees. Pest Mgt. Sci. 73:904-916.

U.S. Department of Agriculture. 2012. United States standards for grades of grapefruit Juice. U.S. Dept. Agr., Washington, DC. 20 Jan. 2020. $<$ https://www.ams.usda.gov/sites/default/files/ media/Canned_Grapefruit_Juice_Standard $\% 5 \mathrm{~B} 1 \%$ 5D.pdf $>$.

U.S. Department of Agriculture. 2018. Florida citrus statistics 2017-2018. National Agricultural Statistics Service. U.S. Dept. Agr., Bartow, FL. 20 Jan. 2020. <https://www.nass.usda. gov/Statistics_by_State/Florida/Publications/ Citrus/Citrus_Statistics/2017-18/fcs1718.pdf>.

U.S. Department of Agriculture. 2020. Natural resources conservation service. Web soil survey. U.S. Dept. Agr., Washington, DC. 20 Jan.
2020. <https://websoilsurvey.sc.egov.usda.gov/ App/WebSoilSurvey.aspx $>$.

Vashisth, T. and J. Grosser. 2018. Comparison of controlled release fertilizer (CRF) for newly planted sweet orange trees under Huanglongbing prevalent conditions. J. Hort. 5, doi: 10.4172/ 2376-0354.1000244.

Vincent, C., T. Vashisth, M. Zekri, and U. Albrecht. 2019. 2019-2020 Florida citrus production guide: Grove planning and establishment. HS1302. Univ. of Florida IFAS. 20 Jan. 2020. <https://edis.ifas.ufl. edu/pdffiles/HS/HS130200.pdf $>$.

Wright, G.C. 2000. Irrigating citrus trees. Cooperative extension. University of Arizona. College of Agriculture. AZ1151.20 Jan. 2020. <https:// extension.arizona.edu/sites/extension.arizona.edu/ files/pubs/az1151.pdf>
Xia, Y., G. Ouyang, R.A. Sequeira, Y. Takeuchi, I. Baez, and J. Chen. 2011. A review of Huanglongbing (citrus greening) management in citrus using nutritional approaches in China. Plant Health Prog. 12:24.

Zaman, Q.U. and A.W. Schumann. 2005. Performance of an ultrasonic tree volume measurement system in commercial citrus groves. Precis. Agr. 6:467-480.

Zambon, F.T., D.M. Kadyampakeni, and J.W. Grosser. 2019. Ground application of overdoses of manganese have a therapeutic effect on sweet orange trees infected with Candidatus Liberibacter asiaticus. HortScience 54:1077-1086.

Zekri, M. and R.C.J. Koo. 1992. Use of controlledrelease fertilizers for young citrus trees. Scientia Hort. 49:233-241. 